Dr Patrycja Zwiech

Department of Microeconomics

University of Szczecin

64, Mickiewicza Street, 71-101 Szczecin, Poland

Phone +4891/4442092, fax $+4891 / 4442137$

E-mail: patrycjazwiech@tlen.pl, http://mikro.univ.szczecin.pl/zwiech

\title{
WHY ARE WOMEN DISCRIMINATED AGAINST ON THE LABOUR MARKET IN POLAND? - THE RESULTS OF THE QUESTIONNAIRE SURVEY
}

\begin{abstract}
As far as professional life is concerned, major differences are observed with reference to the situation of women and men, which is reflected in the research indicating that women occupy worse position on the labour market and showing the determinants of such a situation. Women earn less, hold lower positions, receive professional training more seldom than men and have greater problems getting a job in the majority of the EU Member States (including Poland). Although complex legislation on equal rights for women has come into force in the European Union, providing the legislation on equal rights for women does not automatically entail economic equality. The present paper aims at drawing the attention of Ukrainian researchers and practitioners in the field of economics to issues relating to discrimination against women and particularly to the reasons for such a state of affairs and to the necessity for adjusting to legal determinants.

The paper presents questionnaire survey on discrimination against women on the labour market. The group of 602 persons holding managerial position participated in the survey. The group examined consisted of 304 managers and 298 manageresses from three subregions of Poland, namely szczeciński, koszaliński and poznański. The survey was conducted in June and July 2004.

The paper attempts to answer the fundamental question, namely why women are discriminated against on the labour market in Poland. Seeking the answer, factors potentially affecting discrimination against women on the labour market have been grouped into four spheres. These groups included the following: determinants on a micro scale referring to women themselves; determinants on a micro scale referring to enterprises, employers and employees; the remaining determinants on a micro scale as well as determinants on a macro scale.
\end{abstract}

Key words: : discrimination against women, gender studies, Poland 